\title{
Keanekaragaman Fitoplankton Sungai Ciliwung Pasca Kegiatan Bersih Ciliwung
}

\author{
Arief Pambudi ${ }^{1}$, Taufiq W Priambodo ${ }^{2}$, Nita Noriko $^{3}$, Basma $^{4}$ \\ ${ }^{1,2,3,4}$ Program Studi Biologi (Bioteknologi), Fakultas Sains dan Teknologi, \\ Universitas Al Azhar Indonesia, Jalan Sisingamangaraja, Kompleks Masjid Agung al Azhar, \\ Kebayoran Baru, Jakarta Selatan 12110
}

Penulis untuk Korespondensi/E-mail: pambudi@uai.ac.id

\begin{abstract}
Abstrak - Sungai Ciliwung merupakan salah satu sungai yang tercemar karena banyak dimanfaatkan oleh warga jakarta diantaranya untuk kegiatan industri dan rumah tangga. Salah satu parameter biologi yang dapat digunakan sebagai indikator perubahan lingkungan yaitu Fitoplankton. Peran fitoplankton dalam ekosistem perairan yaitu sebagai produsen primer, hal ini karena fitoplankton memiliki kemampuan untuk fotosintesis. Penelitian ini dilaksanakan pada bulan Februari sampai dengan Juli 2016. Kegiatan Bersih Ciliwung dilaksanakan dari Rindam Jaya, Condet menuju Bidara Cina. Pasca kegiatan bersih ciliwung nilai oksigen terlarut (DO) dari hulu Rindam Jaya (Condet) menuju hilir hingga Bidara Cina mengalami penurunan, sehingga dapat mempengaruhi keanekaragaman fitoplankton. Perbedaan ini diduga memberikan gambaran keragaman komunitas fitoplankton yang berbeda sehingga dilakukan pengambilan sampel fitoplankton di kedua titik tersebut masing-masing dengan 3 kali pengulangan. Metode pengambilan sampel fitoplankton yang digunakan yaitu metode sampling Horizontal dan sampel diidentifikasi menggunakan Sedgewick Rafter Cell Counting (SRCC). Berdasarkan penelitian, total kelimpahan di Rindam Jaya lebih tinggi dibandingkan di Bidara Cina dengan angka berturut-turut 2511 Ind/L dan 1495 Ind/L. Hasil identifikasi fitoplankton yang ditemukan pada lokasi penelitian sebanyak 53 genus yang termasuk ke dalam 5 divisi yaitu, Bacillariophyta (20), Chlorophyta (16), Chrysophyta (5), Cyanophyta (8), dan Rhodophyta (4). Kelimpahan fitoplankton pada stasiun Rindam jaya lebih tinggi dibandingkan di Bidara Cina.
\end{abstract}

\section{Kata Kunci - Fitoplankton, Sungai Ciliwung, BioIndikator}

Abstract - Ciliwung river is one of the most polluted rivers because it's used by many citizens of Jakarta for Industrial and household activity. One of biological parameter that's can be used as an indicator of environmental changed is Phytoplankton. The role of phytoplankton in aquatic ecosystem that is as primary producers, this is because phytoplankton have the ability to photosytensis. This study was conducted from February to July 2016. Ciliwung clean activity is implemented from Rindam Jaya, Condet to Bidara Cina. Post-activity clean ciliwung value of dissolved-oxygen from upstream Ridam Jaya, Condet to downsream Bidara Cina decreased, so that it can affect the diversity of phytoplankton. This difference is thought to give a picture of the diversity of different phytoplankton community so that samples were taken of phytoplankton in two points each with three repetitions. Phytoplankton sampling method was used Horizontal sampling method and samples were identified using Sedgewick Rafter Cell Counting (SRCC). Based on the research, the total abundance in Rindam Jaya is higher than in Bidara Cina with consecutive numbers 2511 Ind / $L$ and 1495 Ind / L. The results of phytoplankton identification were found in the study sites of 53 genera belonging to 5 divisions namely, Bacillariophyta (20), Chlorophyta (16), Chrysophyta (5), Cyanophyta (8), and Rhodophyta (4). The abundance of phytoplankton at Rindam Jaya station is higher than in Bidara Cina.

Keyword - Phytoplankton, Ciliwung River, Indicator Biotecnology 


\section{PENDAHULUAN}

$\mathrm{S}$ ungai Ciliwung merupakan salah satu sungai yang bantaran sungainya banyak dimanfaatkan untuk pemukiman warga, sehingga dari pemanfaatan tersebut menghasilkan sampah dan limbah rumah tangga yang langsung dibuang ke perairan sungai yang menyebabkan sungai menjadi tercemar dan penurunan kualitas perairan (Hendrawan et al. 2004). Salah satu bioindikator adanya perubahan lingkungan perairan yaitu fitoplankton (Fachrul et al. 2008). Fitoplankton merupakan organisme mikroskopik yang hidup melayang di dalam air, berperan sebagai produser primer dalam rantai makanan pada semua perairan alami (Adithya 2014). Fitoplankton memiliki klorofil sehingga mampu berfotosintesis. Bahan organik hasil fotosintesis inilah yang menjadi makanan dan sumber energi yang menghidupkan seluruh fungsi ekosistem di perairan, sehingga fitoplankton memiliki peran yang sangat penting dalam ekosistem perairan (Nontji 2008).

Mulai Februari 2015, pasca kegiatan Bersih Ciliwung kondisi fisik sungai Ciliwung mengalami perubahan lebih baik dengan penurunan nilai DO dari hulu Rindam Jaya (Condet) menuju hilir, Bidara Cina (kp. Melayu) (Noriko et al. 2015), perbedaan ini diduga memberikan gambaran keragaman komunitas fitoplankton yang berbeda pula. Oleh karena itu gambaran biologis lebih jelas mengenai kondisi perairan dibeberapa titik sungai Ciliwung perlu dan dapat diteliti lebih

$\begin{array}{cc}\begin{array}{c}\text { Penentuan Titik } \\ \text { Pengambilan } \\ \text { Sampel }\end{array} & \begin{array}{c}\text { Pengambilan } \\ \text { Sampel } \\ \text { Fitoplankton }\end{array} \\ & \end{array}$

lanjut melalui identifikasi komunitas fitoplankton. Parameter keragaman fitoplankton yang didukung data fisik lingkungan pada lokasi yang berbeda dapat menjadi evaluasi tingkat keberhasilan kegiatan Ciliwung bersih untuk mengembalikan fungsinya.

\section{Tujuan dan Manfaat Penelitian}

Penelitian ini dilakukan untuk mengetahui keragaman fitoplankton serta mendapatkan data pendukung suhu, pH, Oksigen Dioksida (DO), Biochemical Oxygen Demand (BOD), Chemycal Oxygen Demand (COD), kecerahan , fosfat, dan nitrat di dua titik berbeda perairan Ciliwung. Manfaat dari penelitian ini adalah sebagai sumber informasi mengenai jenis Fitoplankton yang dapat dijadikan sebagai indikator lingkungan perairan serta mengetahui tingkat pencemaran perairan.

\section{METODOLOGI}

\section{Waktu dan Lokasi Penelitian}

Penelitian dilaksanakan di perairan sungai Ciliwung pada bulan Februari-Juni 2016. Pengambilan sampel air dilakukan bertepatan pada musim hujan. Identifikasi fitoplankton dilakukan di Laboratorium Mikrobiologi Universitas Al-Azhar Indonesia (UAI) dan untuk analisis fisika dan kimia air dilakukan di Laboratorium Pengujian Fakultas Teknologi Pertanian IPB Darmaga, Bogor. Penelitian ini dilaksanakan melalui beberapa tahap (Gambar $1)$.

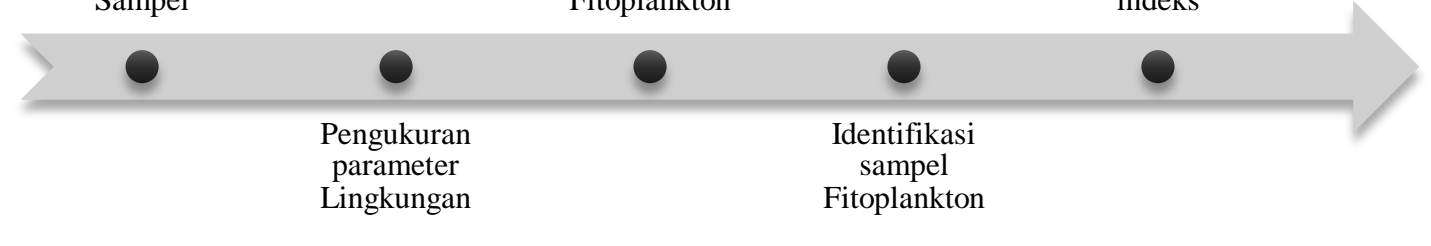

Gambar 1 Tahapan Penelitian.

\section{Penentuan Titik Pengambilan Sampel}

Penentuan titik sampel ditentukan selain berlandaskan nilai DO hasil penelitian yang pernah dilakukan Noriko et al. (2015), tapi juga berdasarkan karakteristik. Stasiun 1 yaitu Rindam Jaya, Condet (sebagai perwakilan daerah jarang penduduk dan kondisi air cukup baik) dan stasiun 2 yaitu Kampung Melayu (sebagai perwakilan daerah padat penduduk dan kondisi air yang buruk).

\section{Pengukuran Parameter Lingkungan}

Beberapa parameter fisika dan kimia air juga dihitung sebagai data pendukung dan dilakukan pada tiap stasiun yang dilakukan bersamaan pada saat pengambilan sampel fitoplankton. 
Adapun parameter tersebut meliputi kecepatan arus (batu apung dan tali), suhu (Termometer), pH (pH meter), kecerahan (Secchi Disk), DO (DO meter), BOD (Lab), COD (Lab), fosfat dan nitrat (Lab) (Rashidy et al. 2013).

\section{Pengambilan Sampel Fitoplankton}

Pengambilan sampel dilakukan pukul 8.00 12.00 WIB. Pengambilan sampel air dilakukan pada bagian permukaan. Metode Pengambilan sampel fitoplankton dilakukan dengan menggunakan metode sampling horizontal yaitu dengan Planktone Net ditarik sesuai jarak yang kita tentukan. Planktone Net yang sudah terikat dengan tali dilempar sejauh 5 meter, kemudian tali ditarik perlahan. Sampel air yang tersaring dalam botol penampung dipindahkan ke botol penyimpanan dan ditetesi formalin \pm 1 $\mathrm{ml}$ kedalam $250 \mathrm{ml}$ air sampel untuk pengawetan. Masing-masing botol diberi label sesuai dengan stasiunnya. Masing-masing stasiun dilakukan tiga kali pengulangan.

\section{Identifikasi Sampel Fitoplankton}

Pertama-tama sampel fitoplankton dihomogenkan kemudian diambil sebanyak 1 $\mathrm{ml}$ dan dimasukkan ke dalam SRCC setelah itu ditutup menggunakan cover glass. Sampel diamati dibawah mikroskop dengan perbesaran 10x10. Fitoplankton yang ditemukan dihitung menggunakan counter dan didokumentasikan. Identifikasi fitoplankton menggunakan buku Edmondson (1963), Mizuno (1978) dan Sheath\&Wehr (2003) (Sachlan 1982).

\section{Analisis Laboratorium}

Sampel fitoplankton dicacah menggunakan Sedgwick-Rafter Cell, yaitu berupa gelas preparat berbentuk empat persegi panjang (APHA 1989). Fitoplankton yang terdapat di perairan sungai Ciliwung diamati dengan mikroskop dan diidentifikasi menggunakan buku dari Edmondson (1963), Mizuno (1978) dan Sheath\&Wehr (2003). Sampel fitoplankton diidentifikasi hingga tingkat genus. Identifikasi dilakukan di Laboratorium mikrobiologi Universitas Al-Azhar Indonesia, Jakarta.

\section{Analisis Data}

\section{Kelimpahan Fitoplankton}

Kelimpahan fitoplankton dihitung berdasarkan metode sapuan diatas Sedgwick Rafter Counting Cell (SRCC). Kelimpahan plankton dinyatakan secara kuantitatif dalam jumlah sel/liter, dihitung berdasarkan rumus (Fachrul, 2008):

$$
\mathrm{N}=\mathrm{n} \times\left(\frac{V r}{V o}\right) \times\left(\frac{1}{V s}\right)
$$

Keterangan:

$\mathrm{N}=$ Jumlah sel per liter

$\mathrm{n} \quad$ = Jumlah sel yang diamati

$\mathrm{Vr}=$ Volume sampel $(\mathrm{ml})$

Vo = Volume air yang diamati (pada SRC) (ml)

$\mathrm{Vs}=$ Volume air yang tersaring

\section{Indeks keanekaragaman (H')}

Analisis indeks keanekaragaman digunakan untuk mengetahui keanekaragaman jenis organisme akuatik. Persamaan yang digunakan untuk menghitung indeks ini adalah persamaan Shannon-Wiener seperti berikut (Odum 1993).

$$
\mathrm{H}=-\sum_{i-0}^{i} p i \ln p i
$$

Keterangan:

H' : Indeks Keanekaragaman ShannonWiener

$\mathrm{S} \quad$ : Jumlah spesies

$\mathrm{Pi} \quad: \mathrm{ni} / \mathrm{N}$

ni : jumlah individu spesies $\mathrm{i}$

$\mathrm{N}$ : jumlah total plankton

Kisaran nilai indeks keanekaragaman dapat diklasifikasikan sebagai berikut :

$\mathrm{H}^{\prime}<2,306=$ keanekaragaman rendah

$2,3026<\mathrm{H}^{\prime}<6,9076=$ keanekaragaman sedang

$$
H^{\prime}>6,9078=\text { keanekaragaman tinggi }
$$

\section{Indeks keseragaman ( $\left.E^{\prime}\right)$}

Indeks keseragaman digunakan untuk menunjukkan sebaran fitoplankton dalam suatu komunitas. Indeks keseragaman juga dihitung dengan formula dari Shannon-Wiener, yaitu sebagai berikut :

$$
\mathrm{E}=\frac{H^{\prime}}{\text { Hmaks }}
$$

Keterangan :

$\mathrm{E}=$ Indeks keseragaman

$\mathrm{H}^{\prime}=$ Indeks keanekaragaman Shannon-Wiener

Hmaks = Ln $\mathrm{S}$ (indeks keanekaragaman maksimum)

$\mathrm{S}=$ Jumlah genus yang ditemukan

Nilai indeks keseragaman berkisar antara 0-1. Semakin kecil nilai E menunjukkan semakin 
kecil pula keseragaman populasi fitoplankton, artinya penyebaran jumlah individu tiap genus tidak sama dan ada kecenderungan bahwa suatu genus mendominasi populasi tersebut. Sebaliknya semakin besar nilai E, maka populasi menunjukkan keseragaman, yaitu bahwa jumlah individu setiap genus dapat dikatakan sama atau tidak jauh berbeda (Odum 1993).

\section{Indeks Dominansi (C)}

Indeks dominansi digunakan untuk melihat adanya dominansi oleh jenis tertentu pada populasi fitoplankton dengan menggunakan Indeks Dominansi Simpson dengan rumus sebagai berikut :

$$
\mathrm{C}=\sum_{i=0}^{i}\left(\frac{n i}{N}\right)^{2}
$$

Keterangan :

C $=$ Indeks dominansi Simpson

$\mathrm{ni}=$ Jumlah individu jenis ke-i

$\mathrm{N}=$ Jumlah total individu

$\mathrm{S}=$ Jumlah genus

Nilai $\mathrm{C}$ berkisar antara $0-1$. Apabila nilai $\mathrm{C}$ mendekati 0 berarti hampir tidak ada individu yang mendominasi dan biasanya diikuti dengan nilai $\mathrm{C}$ yang besar (mendekati 1), sedangkan apabila nilai $\mathrm{C}$ mendekati 1 berarti terjadi dominansi jenis tertentu dan dicirikan dengan nilai $\mathrm{C}$ yang lebih kecil atau mendekati 0 (Odum 1993).

\section{HASIL DAN PEMBAHASAN}

\section{Parameter Fisika dan Kimia Sungai Ciliwung}

Keberadaan fitoplankton sangat dipengaruhi oleh kondisi fisika dan kimia perairan. Untuk itu, dilakukan perhitungan beberapa parameter lingkungan meliputi kondisi fisik dan kimia seperti tercantum pada Tabel 1.
Tabel 1. Parameter lingkungan pada kedua stasiun pengamatan

\begin{tabular}{lcc}
\hline \multirow{2}{*}{ Parameter } & \multicolumn{2}{c}{ Nilai } \\
\cline { 2 - 3 } & Rindam Jaya & BidaraCina \\
\hline $\begin{array}{l}\text { Kecerahan } \\
(\mathrm{cm})\end{array}$ & 4,67 & 6,00 \\
\hline $\begin{array}{l}\text { Kecepatan } \\
\text { Arus }\end{array}$ & & \\
$\begin{array}{l}\text { Permukaan } \\
(\mathrm{m} / \mathrm{s})\end{array}$ & 0,17 & 0,66 \\
\hline $\mathrm{pH}$ & & \\
\hline DO $(\mathrm{mg} / \mathrm{L})$ & 3,76 & 3,05 \\
\hline BOD $(\mathrm{mg} / \mathrm{l})$ & 29 & 30 \\
\hline $\mathrm{COD}(\mathrm{mg} / \mathrm{l})$ & 78 & 76 \\
\hline Suhu $\left({ }^{\circ} \mathrm{C}\right)$ & 31 & 28,8 \\
\hline Phosfat $(\mathrm{mg} / \mathrm{l})$ & 0,472 & 0,511 \\
\hline Nitrat $(\mathrm{mg} / \mathrm{l})$ & 12,97 & 16,75 \\
\hline
\end{tabular}

Kecerahan di stasiun Rindam Jaya 4,67 cm dan di stasiun Bidara Cina yaitu $6 \mathrm{~cm}$ yang menunjukkan tingkat kecerahan di sungai Ciliwung sangat rendah. Rendahnya tingkat kecerahan disebabkan arus yang tinggi pada bagian bawah permukaan air, sedangkan pada permukaan air terlihat tidak begitu tinggi. Hal ini menyebabkan terjadinya pusaran dan turbulensi air yang membuat partikel lumpur seperti teraduk dan membuat air menjadi keruh. Beberapa penyebab lain suatu perairan memiliki tingkat kecerahan rendah diantaranya jumlah dan jenis unsur atau bahan terlarut dalam perairan baik berbentuk mineral seperti lumpur/tanah maupun yang berbentuk senyawa organik seperti plankton (Nugroho 2006).

Kecepatan arus dalam suatu badan air sangat mempengaruhi kolom air yang terus berubah, sehingga hal ini berpengaruh pada keterserdiaan nutrien yang relatif lebih rendah karena terus tercuci akibat pergantian air yang terus menerus (Sudiana 2005). Hasil pengukuran arus permukaan sungai Ciliwung di stasiun Rindam Jaya dan Bidara Cina secara berturut-turut menunjukkan $0,17 \mathrm{~m} /$ detik dan $0,6 \mathrm{~m} /$ detik. Arus permukaan di Rindam Jaya relatif lebih rendah dibandingkan Bidara Cina sehingga dapat menyebabkan perbedaan penyebaran fitoplankton. Menurut Odum (1988) dan Abel (1989) perairan yang relatif tenang merupakan habitat yang cocok untuk fitoplankton. Sehingga arus deras di kedua titik 
penelitian dianggap kurang mendukung untuk kehidupan fitoplankton.

Berdasarkan hasil pengamatan, nilai $\mathrm{pH}$ antara stasiun Rindam Jaya dan Bidara Cina menunjukkan hasil yang sama besar. Besarnya nilai $\mathrm{pH}$ sangat menentukan dominansi fitoplankton di perairan. Nilai $\mathrm{pH}$ tersebut masih berada pada kisaran nilai yang baik untuk kehidupan biota perairan (Effendi 2003).

Pengukuran DO pada dua stasiun penelitian yaitu di Rindam Jaya dan Bidara Cina pada perairan sungai Ciliwung diperoleh hasil 3,76 $\mathrm{mg} / \mathrm{L}$ dan 3,053 mg/L. Angka pengukuran ini lebih tinggi secara signifikan dibandingkan pengukuran yang dilakukan Noriko et al. (2015) yang dilakukan di musim kemarau (Agustus-September) saat permukaan air sungai Ciliwung rendah $(2,08 \mathrm{mg} / \mathrm{L}$ untuk Rindam Jaya dan $0,41 \mathrm{mg} / \mathrm{L}$ untuk Bidara Cina). Angka tersebut termasuk tercemar sedang sehingga Fitoplankton masih bisa hidup di perairan tersebut dengan kelebihan memiliki daya toleransi yang tinggi. Fluktuasi oksigen terlarut dalam suatu perairan dipengaruhi oleh banyaknya fitoplankton yang menggunakan oksigen terlarut untuk respirasi dan proses fotosintesis (Simanjuntak 2007). Lingkungan yang tidak menguntungkan bagi fitoplankton dapat menyebabkan kelimpahan berkurang dan dapat mempengaruhi tingkat kesuburan perairan (Nugroho 2006).

Hasil pengukuran suhu menunjukkan bahwa suhu air di Rindam Jaya yaitu $31^{\circ} \mathrm{C}$ dan di Bidara Cina yaitu $29^{\circ} \mathrm{C}$. Suhu yang tinggi pada kedua stasiun disebabkan oleh tidak adanya naungan vegetasi (kanopi) akibat penggundulan bantaran Daerah Aliran Sungai sebagai wilayah steril yang telah dibeton. Hal ini yang menyebabkan hilangnya perlindungan sehingga badan air terkena cahaya matahari secara langsung. Menurut Barus (2004), tinggi rendahnya suhu dipengaruhi oleh berbagai faktor seperti intensitas cahaya matahari, pertukaran panas antara air dengan udara sekelilingnya, ketinggian geografis dan juga oleh faktor kanopi (penutupan oleh vegetasi) dari pepohonan yang tumbuh di tepi. Faktor lainnya juga diakibatkan oleh manusia seperti limbah panas yang berasal dari air pendingin pabrik, penggundulan Daerah Aliran Sungai yang menyebabkan hilangnya perlindungan sehingga badan air terkena cahaya matahari secara langsung (Siregar 2009).

\section{Fitoplankton di Sungai Ciliwung}

Hasil pengamatan fitoplankton dari dua titik stasiun di sungai Ciliwung yaitu Rindam Jaya ditemukan jumlah total fitoplankton sebanyak 3443 dan Bidara Cina 2391. Hasil identifikasi fitoplankton dari sampel air sungai Ciliwung ditemukan fitoplankton yang berasal dari 5 divisi di antaranya Bacillariophyta dengan 20 genus, Chlorophyta 16 genus, Chrysophyta 5 genus, Cyanophyta 8 genus, dan Rhodophyta 4 genus. Total jumlah divisi Bacillariophyta di Rindam Jaya dan Bidara Cina berturut-turut adalah 2328 Ind/L dan 1378 Ind/L. Berdasarkan data yang telah diperoleh tersebut, terlihat bahwa kontribusi tertinggi dari kelimpahan fitoplankton adalah divisi Bacillariophyta. Dominannya Bacillariophyta dibanding kelompok lain merupakan hal yang umum terjadi pada bagian perairan yang mengalami mixing sempurna yang diakibatkan oleh mixing pasang surut dan perubahan karena pasang surut secara terus menerus (Badylak \& Phylips 2004). Walaupun sungai tidak mengalami pasang surut, namun keberadaan arus dan turbulensi air dapat dianalogikan dengan percampuran akibat pasang surut.

\section{Keanekaragaman Fitoplankton Tiap Divisi}

\section{a. Divisi Bacillariophyta}

Kelimpahan divisi Bacillariophyta merupakan yang tertinggi dibandingkan divisi lainnya. Lima genus dengan kelimpahan tertinggi antar lain Navicula, Nitzschia, Synedra, Cymbella, dan Fragilaria (Tabel 2). Selain itu, genus yang hanya ditemukan di stasiun Rindam Jaya di antaranya Gyrosigma, Aulacoseira, Cyclotella dan Stenopterobia. Sedangkan genus yang hanya ditemukan pada Bidara Cina di antaranya Surirella, Centronella, Melosira dan Aneumastus. Genus yang dominan di kedua stasiun pengamatan berturut- turut adalah Navicula (760 Ind/L dan 471 Ind/L), Synedra (610 Ind/L dan 411 Ind/L) dan Nitzschia (543 Ind/L dan 206 Ind/L).

Genus-genus yang melimpah tersebut merupakan genus yang mempunyai daya toleransi tinggi, selain itu didukung oleh kondisi perairan cukup mengandung unsur hara yang diperlukan untuk perkembangan fitoplankton yaitu fosfat dan nitrat yang berasal 
dari buangan limbah rumah tangga dan industri (Piirsoo et al. 2008). Selain itu pH 7,05 yang diperoleh pada penelitian mendekati ideal yang mendukung kemelimpahan diatom yaitu pada kisaran $\mathrm{pH}$ yang netral (Weitzel 1979). Faktor lingkungan lainnya yang mendukung kelimpahan divisi ini yaitu suhu. Diatom akan tumbuh dengan baik pada kisaran $20^{\circ}-30^{\circ} \mathrm{C}$ (Effendi 2003).

Tabel 2. Keragaman fitoplankton dari divisi Bacillariophyta pada kedua stasiun pengamatan

\begin{tabular}{|c|c|c|c|}
\hline \multirow{3}{*}{$\begin{array}{l}\text { Genus } \\
\text { Fitoplankton }\end{array}$} & \multirow{3}{*}{$\begin{array}{l}\text { Divisi } \\
\text { Fitoplankton }\end{array}$} & \multicolumn{2}{|c|}{$\begin{array}{l}\text { Kelimpahan } \\
\text { (Ind/L) }\end{array}$} \\
\hline & & \multicolumn{2}{|c|}{ Rindam Bidara } \\
\hline & & Jaya & Cina \\
\hline Navicula & Bacillariophyta & 760 & 471 \\
\hline Nitzschia & Bacillariophyta & 543 & 206 \\
\hline Synedra & Bacillariophyta & 610 & 411 \\
\hline Fragilaria & Bacillariophyta & 96 & 69 \\
\hline Pinnularia & Bacillariophyta & 35 & 32 \\
\hline Diatoma & Bacillariophyta & 3 & 6 \\
\hline Cymbella & Bacillariophyta & 188 & 96 \\
\hline Diadesmis & Bacillariophyta & 6 & 3 \\
\hline Ephitemia & Bacillariophyta & 17 & 20 \\
\hline Gomphonema & Bacillariophyta & 14 & 31 \\
\hline Gyrosigma & Bacillariophyta & 20 & 0 \\
\hline Aulacoseira & Bacillariophyta & 3 & 0 \\
\hline Cyclotella & Bacillariophyta & 3 & 0 \\
\hline Frustulia & Bacillariophyta & 1 & 7 \\
\hline Surirella & Bacillariophyta & 0 & 14 \\
\hline Stenopterobia & Bacillariophyta & 3 & 0 \\
\hline Amphora & Bacillariophyta & 3 & 3 \\
\hline Centronella & Bacillariophyta & 0 & 3 \\
\hline Melosira & Bacillariophyta & 0 & 3 \\
\hline Aneumastus & Bacillariophyta & 0 & 6 \\
\hline Total kelimpaha & & 2305 & 1381 \\
\hline
\end{tabular}

\section{b. Divisi Chlorophyta}

Total divisi Chlorophyta di Rindam Jaya dan Bidara Cina berturut-turut yaitu $79 \mathrm{Ind} / \mathrm{L}$ dan $31 \mathrm{Ind} / \mathrm{L}$. Genus pada divisi ini yang memiliki indeks kelimpahan cukup tinggi di stasiun Rindam jaya di antaranya Stigeoclonium 23 Ind/L, Binucleria 14 Ind/L, dan Cylindropsa 9 Ind/L. Genus yang hanya terdapat pada stasiun Rindam Jaya yaitu Binuclearia, Chroococcus, Closterium, Desmococcus, Draparnaldia,
Euastrum, Scytonema, Treubaria dan Volvox. Sedangkan genus yang hanya ditemukan di stasiun Bidara Cina di antaranya Pediastrum, Scenedesmus dan Tetraedron. Genus yang dominan pada stasiun Rindam Jaya yaitu Stigeoclonium yaitu $24 \mathrm{Ind} / \mathrm{L}$ dan Binucleria 14 Ind/L. Sedangkan genus Cylindrocapsa cukup dominan di kedua stasiun pengamatan berturutturut yaitu $9 \mathrm{Ind} / \mathrm{L}$ dan $14 \mathrm{Ind} / \mathrm{L}$. Genus yang dominan tumbuh dengan baik karena suhu dan pH yang mendukung divisi ini sesuai dengan pernyataan Effendi (2003), bahwa alga dari divisi Chlorophyta akan tumbuh dengan baik pada kisaran suhu $30^{\circ}-35^{\circ} \mathrm{C}$.

Tabel 3. Keragaman fitoplankton dari divisi Chlorophyta pada kedua stasiun pengamatan

\begin{tabular}{llcc}
\hline \multirow{2}{*}{$\begin{array}{l}\text { Genus } \\
\text { Fitoplankton }\end{array}$} & $\begin{array}{c}\text { Divisi } \\
\text { Fitoplankton }\end{array}$ & $\begin{array}{c}\text { Fitoplankton } \\
\text { (nd/L) }\end{array}$ \\
\cline { 3 - 4 } & & $\begin{array}{c}\text { Rindam } \\
\text { Jaya }\end{array}$ & $\begin{array}{c}\text { Bidara } \\
\text { Cina }\end{array}$ \\
\hline Binuclearia & Chlorophyta & 14 & 0 \\
\hline Chroococcus & Chlorophyta & 3 & 0 \\
\hline Closterium & Chlorophyta & 3 & 0 \\
\hline Cladophora & Chlorophyta & 3 & 4 \\
\hline Cylindrocapsa & Chlorophyta & 9 & 14 \\
\hline Desmococcus & Chlorophyta & 3 & 0 \\
\hline Draparnaldia & Chlorophyta & 3 & 0 \\
\hline Euastrum & Chlorophyta & 3 & 0 \\
\hline Oedogonium & Chlorophyta & 0 & 0 \\
\hline Pediastrum & Chlorophyta & 0 & 3 \\
\hline Scenedesmus & Chlorophyta & 0 & 4 \\
\hline Scytonema & Chlorophyta & 3 & 0 \\
\hline Stigeoclonium & Chlorophyta & 24 & 3 \\
\hline Tetraedron & Chlorophyta & 0 & 3 \\
\hline Treubaria & Chlorophyta & 3 & 0 \\
\hline Volvox & Chlorophyta & 8 & 0 \\
\hline Total Kelimpahan & & 79 & 31 \\
\hline & & & \\
\hline
\end{tabular}

Divisi Bacillariophyta dan Chlorophyta merupakan dua genus yang ditemukan di sungai Ciliwung dengan jumlah genus terbanyak jika dibandingkan dengan divisi lainnya. Hal ini sesuai dengan pernyataan Barus (2002) bahwa kelompok fitoplankton yang mendominasi perairan tawar umumnya terdiri dari Bacillariophyta (Diatom) dan Chlorophyta (Ganggang hijau). Kedua divisi ini mempunyai kemampuan baik dalam 
menyesuaikan diri dengan lingkungan dan berkembang biak dengan cepat.

c. Divisi Chrysophyta

Total jumlah divisi Chrysophyta pada stasiun Rindam Jaya dan Bidara Cina berturut-turut adalah 6 Ind/L dan 9 Ind/L. Genus yang ditemukan di antaranya Chrysocapsopsis dan Chrysarachnion. Sedangkan di Bidara Cina di antaranya Chaetoceros, Uroglenopsis dan Limnothrix. Divisi ini memiliki kelimpahan terendah dibandingkan dengan divisi lainnya. Hal ini disebabkan divisi tersebut kurang dapat beradaptasi dengan kondisi lingkungan di kedua stasiun ini, sehingga ekosistem ini kurang ideal bagi divisi tersebut. Salah satunya yaitu perairan sungai yang saat itu berarus deras sehingga fitoplankton terbawa oleh aliran air tersebut. Hal ini sesuai dengan pernyataan Odum (1988) dan Abel (1989), bahwa perairan relatif tenang merupakan habitat yang cocok untuk fitoplankton (Fachrul et al. 2008). Genus Chrysocapsopsis dan Chrysarachnion hanya ditemukan di stasiun Rindam Jaya, sedangkan Chaetoceros, Uroglenopsis dan Limnothrix hanya ditemukan di Bidara Cina.

Tabel 4. Keragaman fitoplankton dari divisi Chrysophyta pada kedua stasiun pengamatan

\begin{tabular}{llcc}
\hline \multirow{2}{*}{$\begin{array}{l}\text { Genus } \\
\text { Fitoplankton }\end{array}$} & $\begin{array}{c}\text { Divisi } \\
\text { Fitoplankton }\end{array}$ & \multicolumn{2}{c}{$\begin{array}{c}\text { Kelimpahan } \\
\text { (Ind/L) }\end{array}$} \\
\cline { 3 - 4 } & & $\begin{array}{c}\text { Rindam } \\
\text { Jaya }\end{array}$ & $\begin{array}{c}\text { Bidara } \\
\text { Cina }\end{array}$ \\
\hline Chaetoceros & Chrysophyta & 0 & 3 \\
\hline Chrysocapsopsis & Chrysophyta & 3 & 0 \\
\hline Chrysarachnion & Chrysophyta & 3 & 0 \\
\hline Uroglenopsis & Chrysophyta & 0 & 3 \\
\hline Limnothrix & Chrysophyta & 0 & 3 \\
\hline Total Kelimpahan & & 6 & 9 \\
\hline
\end{tabular}

\section{d. Divisi Cyanophyta}

Total jumlah divisi Cyanophyta pada stasiun Rindam Jaya dan Bidara Cina berturut-turut adalah $89 \mathrm{Ind} / \mathrm{L}$ dan $25 \mathrm{Ind} / \mathrm{L}$. Genus yang memiliki indeks kelimpahan cukup tinggi di stasiun Rindam Jaya di antaranya Oscillatoria 57 Ind/L, Lyngbya 10 Ind/L dan Spirulina 7 Ind/L. Sedangkan di stasiun Bidara Cina yang kelimpahannya cukup tinggi di antaranya Nodularia 8 Ind/L dan Spirulina 7 ind/L. Genus Anabaena hanya dijumpai pada statsiun Bidara Cina, sedangkan Oscillatoria,
Pseudanabaena dan Tabellaria hanya dijumpai pada stasiun Rindam Jaya. Genus yang dominan pada Rindam Jaya yaitu Oscillatoria 57 Ind/L, sedangkan pada Bidara Cina yaitu Nodularia 8 Ind/L. Berdasarkan Fukuyo (2000) ada beberapa fitoplankton yang dapat menjadi indikator perairan tercemar salah satunya Oscillatoria, hal ini dikarenakan Oscillatoria memiliki reproduksi aseksual berupa spora sehingga sifatnya yang memiliki toleransi tinggi terhadap kondisi perairan yang tercemar (Handayani 2009). Selain itu divisi Cyanophyta lebih dapat bertoleransi terhadap kisaran suhu yang lebih tinggi dibandingkan dengan Chlorophyta dan diatom (Effendi 2003).

Tabel 5. Keragaman fitoplankton dari divisi Cyanophyta pada kedua stasiun pengamatan

\begin{tabular}{|c|c|c|c|}
\hline \multirow{2}{*}{$\begin{array}{l}\text { Genus } \\
\text { Fitoplankton }\end{array}$} & \multirow{2}{*}{$\begin{array}{c}\text { Divisi } \\
\text { Fitoplankton }\end{array}$} & \multicolumn{2}{|c|}{$\begin{array}{c}\text { Kelimpahan } \\
(\text { Ind/L) }\end{array}$} \\
\hline & & $\begin{array}{c}\text { Rindam } \\
\text { Jaya }\end{array}$ & $\begin{array}{l}\text { Bidar } \\
\text { aCina }\end{array}$ \\
\hline Aphanizomeno: & Cyanophyta & 3 & 4 \\
\hline Anabaena & Cyanophyta & 0 & 3 \\
\hline Lyngbya & Cyanophyta & 10 & 3 \\
\hline Nodularia & Cyanophyta & 6 & 8 \\
\hline Oscillatoria & Cyanophyta & 57 & 0 \\
\hline Pseudanabaen & Cyanophyta & 3 & 0 \\
\hline Spirulina & Cyanophyta & 7 & 7 \\
\hline Tabellaria & Cyanophyta & 3 & 0 \\
\hline Total Kelimpaha & & 89 & 25 \\
\hline
\end{tabular}

\section{e. Divisi Rhodophyta}

Total jumlah divisi Rhodophyta pada stasiun Rindam Jaya dan Bidara Cina berturut-turut yaitu 9 Ind/L dan 52 Ind/L. Genus yang ditemukan di Rindam Jaya di antaranya Audouinella, Chroodactylon dan Lemanea. Genus yang ditemukan di Bidara Cina dan kelimpahannya cukup tinggi antara lain genus Lemanea $35 \mathrm{Ind} / \mathrm{L}$, Chroodactylon $8 \mathrm{Ind} / \mathrm{L}$ dan Gracilaria $6 \mathrm{Ind} / \mathrm{L}$. Genus khas yang hanya dijumpai di salah satu stasiun yaitu Gracilaria yang hanya ditemukan di stasiun Bidara Cina. Genus Lemanea merupakan satu-satunya yang paling dominan di stasiun Bidara Cina dengan kelimpahan 35 Ind/L. 
Tabel 7. Keragaman fitoplankton dari divisi Rhodophyyta pada kedua stasiun pengamatan

\begin{tabular}{|c|c|c|c|}
\hline \multirow{2}{*}{$\begin{array}{l}\text { Genus } \\
\text { Fitoplankton }\end{array}$} & \multirow{2}{*}{$\begin{array}{c}\text { Divisi } \\
\text { Fitoplankton }\end{array}$} & \multicolumn{2}{|c|}{$\begin{array}{l}\text { Kelimpahan } \\
\text { (Ind/L) }\end{array}$} \\
\hline & & $\begin{array}{c}\text { Rindam } \\
\text { Jaya }\end{array}$ & $\begin{array}{c}\text { Bidara } \\
\text { Cina } \\
\end{array}$ \\
\hline Audouinella & Rhodophyta & 3 & 3 \\
\hline Chroodactylon & Rhodophyta & 3 & 8 \\
\hline Gracilaria & Rhodophyta & 0 & 6 \\
\hline Lemanea & Rhodophyta & 3 & 35 \\
\hline Total Kelimpaha & & 9 & 52 \\
\hline
\end{tabular}

Setiap divisi terdapat beberapa genus yang hanya dijumpai di salah satu stasiun. Hal ini sesuai dengan pernyataan Onyema (2007), bahwa komposisi fitoplankton tidak selalu merata pada setiap lokasi di dalam suatu ekosistem, di mana pada suatu ekosistem sering ditemukan beberapa jenis melimpah sedangkan yang lain tidak. Keberadaan fitoplankton sangat tergantung pada kondisi lingkungan perairan yang sesuai dengan hidupnya dan dapat menunjang kehidupannya.

Adapun genus yang dominan dalam setiap divisi dikarenakan genus fitoplankton ini mempunyai daya toleransi tinggi dan dapat hidup di dalam keadaan ekosistem seperti pada stasiun tersebut. Serta faktor pendukung seperti fisika dan kimia sudah cukup sesuai dengan kriteria hidupnya.

\section{KESIMPULAN}

Hasil identifikasi fitoplankton yang ditemukan pada lokasi penelitian sebanyak 53 genus yang termasuk ke dalam 5 divisi yaitu, Bacillariophyta (20 genus), Chlorophyta (16 genus), Chrysophya (5 genus), Cyanophyta (8 genus), dan Rhodophyta (4 genus). Total kelimpahan di Rindam Jaya lebih tinggi dibandingkan di Bidara Cina dengan angka berturut-turut 2511 Ind/L dan 1495 Ind/L. Keanekaragaman di stasiun Bidara Cina sedikit lebih tinggi dibandingkan Rindam Jaya namun menurut Shannon Wiener keduanya tergolong rendah dan menunjukkan kualitas perairan yang tercemar ringan. Indeks keseragaman pada Rindam Jaya yaitu 0,53 dan Bidara Cina 0,57. Keduanya mendekati 1, sehingga jumlah individu setiap genus dapat dikatakan sama atau tidak jauh berbeda. Indeks dominansi di kedua stasiun memiliki angka dominansi yang sama. Dan keduanya mendekati 0 yang berarti hampir tidak ada individu yang mendominansi. Pada penelitian ini Faktor biologi (Fitoplankton) dan faktor fisika kimia berkorelasi kuat.

\section{DAFTAR PUSTAKA}

[1] Adithya R. 2014. Keanekaragaman dan kelimpahan fitoplankton di sungai Ekang Anculai kecamatan Teluk Sebong kabupaten Bintan [Skripsi]. FIKP: Universitas Maritim Raja Ali Haji.

[2] Abel PD. 1989. Water Pollution Biology. London: Ellis Horwood. American Public Health Association (APHA). 1995. Standards Methods for The Examination of Water and Wastewater. 19th ed. Washington DC: American Public Health Association Inc.

[3] APHA (American Public Health Association). 1989. Standard Method for the Examinition of Water and Waste Water. American Public Health Association. Water Pollution Control Federation. Port City Press. Baltimore, Mariland. 1202.

[4] Badylak S, Phylips EJ. 2004. Spatial and Temporal Patterns of Phytoplanktons Compotition in a Subtropical Coastal Lagoon, The Indian River Lagoon, Florida, USA. J.Plankton Res: 26 12291247.

[5] Barus TA. 2002. Pengantar Limnologi. Medan: Jurusan Biologi FMIPA Universitas Sumatra Utara.

[6] Barus TA. 2004. Pengantar Limnologi Studi Tentang Ekosistem Air Daratan. Medan: USU Press.

[7] Effendi H. 2003. Telaah Kualitas Air: Bagi Pengelolaan Sumber Daya dan Lingkungan Perairan. Kanisius: Yogyakarta.

[8] Fachrul MF, Haeruman H, Sitepu LC. 2005. Komunitas Fitoplankton Sebagai Bio-Indikator Kualitas Perairan Teluk Jakarta [Skripsi].Jakarta : FMIPA Universitas Indonesia.

[9] Fachrul MF, Ediyono SH, Wulandari M. 2008. Komposisi dan Model Kelimpahan Fitoplankton di Perairan Sungai Ciliwung, Jakarta. Universitas Trisakti (USAKTI). 
Jakarta. Biodiversitas: Volume 9, Hal: 296-300

[10] Fachrul MF. 2008. Metode Sampling Bioekologi. Jakarta: PT Bumi Aksara.

[11] Fukuyo Y. 2000. Red Tide Microalga. fukuyo@mail.ecc.u-tokyo.ac.jp.

[12] Handayani ST, Suharto B, Marsoedi. 2009. Penentuan Status Kualitas Perairan Sungai Brantas Dengan Biomonitoring Makrozoobentos: Tinjauan Dari Pencemaran Bahan Organik. Biosain, Vol. 1 No. 1.

[13] Hendrawaan D, Melati MF, Bestari B. 2004. Kajian Kualitas Perairan Sungai Ciliwung. Jurnal Penelitian Karya Ilmiah Lemlit Usakti 3: 54-66.

[14] Nugroho A. 2006. Bioindikator Kualitas Air. Penerbit Universitas Trisakti: Jakarta.

[15] Nontji A. 2008. Plankton laut. Penerbit: Lembaga Ilmu Pengetahuan Indonesia (LIPI). Jakarta.

[16] Noriko N, Elfidasari D, Effendi Y, Priambodo TW, Yorianta H, Pambudi A, dan Puspitasari RL. 2015. Identifikasi faktor penting untuk mendukung keberhasilan kebijakan Kodam jaya jayakarta pada program ciliwung bersih, indah dan sehat (Studi kasus di wilayah Tanjung Barat, pejaten, Kali Hitam, Condet, Kalibata, Cikoko, MT. Haryono, Kampung Melayu). Proposal Penelitian program studi Biologi, Universitas AlAzhar Indonesia.

[17] Odum, E.P. 1988. Fundamental of Ecology. Phidelphia: W.B. Sounders Company.

[18] Odum EP. 1993. Fundamental of Ecology. Philadelphia: W. B: Souders Company.
[19] Onyema IC. 2007. The Phytoplankton Composition. Abundance and Temporal Variation of a Polluted Estuarine Creek in Lagos, Nigeria. Turkish Journal of Fisheries and Aquatic Sciences, 7, pp.8996.

[20] Piirsoo K, Peeter P, Tuvikene A, and Malle V. 2008. Temporal and spatial patterns of phytoplankton in a temperate lowland river (Emajo gi, Estonia). Journal of Plankton Research 30: 1285-1295.

[21] Rashidy EA, Litaay M, Salam MA, Umar MR. 2013. Komposisi dan kelimpahan fitoplankton di perairan pantai Kelurahan Tekolabbua, Kecamatan Pangkajene, Kabupaten Pangkep, Provinsi Sulawesi Selatan. Jurnal Alam Lingkungan 4: 12-18

[22] Reynold CS. 1993. Scales of Disturbance and Tehir Role in Plankton Ecology. Hydrobiology (249) : 157-171.

[23] Sachlan M. 1982. Planktonologi. Fakultas Peternakan dan Perikanan Universitas Diponegoro. Semarang. Hlm 177.

[24] Siregar MH. 2009. Studi keanekaragaman plankton di hulu sungai Asahan Porsea [Skripsi]. Medan (Id): Universitas Sumetera Utara.

[25] Simanjuntak M. 2007. Oksigen terlarut dan apparent oxygen utilization di Perairan Teluk Klabat, Pulau Bangka. Jurnal Ilmu Kelautan 12 : 59-66.

[26] Yazwar. 2008. Keanekaragaman Plankton dan Keterkaitannya Dengan Kualitas Air Di Parapat Danau Toba [Skripsi]. USU: Medan.

[27] Weitzel RL. 1979. Methods and Measuremants of Perifiton Communities: A Review American Society for Testing and Materials: Philadelphia. 